\title{
A Unified Account of Glory Concepts: Glory, Glorious, Glorified, Glorying-in, and Derivative Concepts
}

\author{
Paul Silva, Jr. \\ University of Cologne \\ Brandon Szerlip \\ Westminster Theological Seminary
}

\begin{abstract}
The term 'glory' is notoriously difficult to characterize. In general, when theologians and philosophers have sought to characterize the term they do so in an imprecise and vague manner that leaves a variety of questions unanswered. In what follows we show how recent work in philosophy together with various historical and theological reflections about glory can be used to elucidate the wide range of concepts that tend to be expressed with the term 'glory' in theological thought.
\end{abstract}

Keywords: glory, praise, respect, admiration, luminosity

\section{Introduction}

Glory figures centrally in the biblical texts. We are told that God has glory (Deut 5:24; Ps 19:1; Isa 35:2; Rom 1:23), that people are to give glory to God (1 Sam 6:5; Isa 24:15; Matt 5:16; Rev 4:9), that glory awaits believers (Rom 8:18; 1 Thess 2:12), that Jesus will return in glory (Matt 24:30; Mark 8:38), and that we are not to seek our own glory (Prov 25:27; John 5:44, 7:18). The list could easily continue. Doubtless, it's the importance of glory in biblical texts that's responsible for the fact that glory is, and has always been, so frequently involved in theological reflection throughout church history. But what, exactly, is glory?

We should pause here. Since we should not expect a single answer to this question. The term 'glory' is a nominalization used to express distinct concepts. On the one hand, 'glory' is used to refer to an attribute. For example, when the biblical texts and theologians discuss "the glory of God" they typically have in mind God's attribute of being glorious. But the word 'glory' is sometimes used to refer to different activities. For example, biblical texts and theologians discuss people glorifying God (or equivalently, God being glorified by people), and they also discuss people glorying in God. In both cases they are referring to the activities of agents. As we will see, there are more glory-concepts than these that are used by theologians. So what we are

Journal of Analytic Theology, Vol. 8, August 2020

10.12978/jat.2020-8.1500111808-65

(C) 2020 Paul Silva, Jr., Brandon Szerlip • (C) 2020 Journal of Analytic Theology 
really after is an account of these varied and distinct glory-concepts that are expressed with the noun 'glory'. Moreover, we are after an account of these distinct glory-concepts that explains just how they are all related to each other.

Our aim is to advance the theology of glory by advancing our understanding of core glory-concepts. We'll first develop an account of what it is to be glorified (section 2 ), and then propose a fitting-attitude analysis of what it is for something to be glorious (section 3). The basic idea will be that being glorious just is being worthy of being glorified. We will then provide an account of derivative notions of glorifying something and as well as derivative notions of glorying-in something that are theologically relevant (section 4). Finally, we explain the connection between glory and luminosity concepts, such as being spectacular and being radiant (section 5).

Before moving forward we'd like to stave-off a concern. Some of the claims we defend are implicit (and sometimes explicit) in existing discussions of glory. In fact, throughout the paper it will be apparent that much of (but by no means most of) what we have to say about glory was present in the thought of Aquinas, Johnathan Edwards, and other philosophical and theological luminaries. This is a virtue, not a vice. For it's evidence that the account we offer of our distinct glory-concepts is accurate and likely to be endorsed by others. The thing to note is what we add to existing discussions of glory: clarity, precision, and thoroughness. A cost of this level of care is breadth in scope: inevitably, we will have to leave many substantive theological, exegetical, and philosophical questions concerning glory unaddressed. Our hope is that this account of our glory-concepts proves useful in addressing further philosophical and theological issues related to glory.

\section{Glorifying: the primary sense}

Glory is often associated with concepts like being magnificent (marvelous, majestic). At other times glory is associated with concepts that somehow involve luminosity, like being spectacular (brilliant, radiant, dazzling). Both kinds of concepts involve reference to attributes, and they are arguably synonymous or near synonymous with the concept of being glorious. Because of their nearness in meaning to the idea of being glorious we cannot easily provide an informative account of being glorious in terms of them. Doing so would quickly push our question back a step: if being glorious is just being magnificent or being spectacular, then what is it to be magnificent or spectacular? We'll return to the notion of being glorious in section 3 and discuss its connection to luminosity-involving concepts like being spectacular in section 5 .

There is an alternative place for us to begin, one we have found to be quite fruitful. It involves thinking about what it is to glorify something. There is a collection of concepts regularly associated with our glory-concepts which we believe are particularly useful for understanding what it is to glorify something. They are the concepts of praise, respect, and admiration. The Oxford English Dictionary likewise confirms the idea that the term 'glory' in English has praise, respect, and admiration among its principal meanings. Hebrew and Greek lexicons confirm that the Hebrew 
and Greek words that are translated as 'glory' in English are words that are regularly used to express the ideas of praise, respect, and admiration in various contexts. ${ }^{1}$

These connections drawn in lexicons and dictionaries are also born out in explicit reflections on glory found in historical sources. For example, Cicero (De Inventione, II, 166) says that "Glory consists in a person's having a widespread reputation accompanied by praise." Making the plausible assumption that having a (good) reputation is at least partly a matter of being respected, Cicero's remark connects glory to both praise and respect. Hobbes (Leviathan, ch. 13) says that the desire for glory is the desire to have "one's associates value him as highly as he values himself; and any sign that he is disregarded or undervalued naturally leads a man to try, as far as he dares, to raise his value in the eyes of others." Talk of being valued and well-regarded are highly suggestive of being admired and respected, and so Hobbes seems to tether glory to something in the neighborhood of admiration and respect. Aquinas (Summa Theologica II-II, q.132. a.2) connects glory to praise and respect when he says that "glory is an effect of honor and praise", and he connects it with something in the ballpark of praise and admiration when he says (Summa Theologica II-II, q.132. a.1) that "the word glory properly denotes that somebody's good is known and approved by many." In his Constitutions of the Society of Jesus Ignatius of Loyola outlines a vision of life whereby everything one does in life is done "for the greater glory of God." And, as George E. Ganass (1991:11) observes, Ignatius uses the term 'glory' throughout his work synonymously with 'praise' and 'honor'. For another example, Jonathan Edwards writes in The End for Which God Created the World (1989, Section VI):

"glory" as the word is used in Scripture, often signifies or implies "praise." This appears from what was observed before, that glory very often signifies honor, which is much the same thing with praise, viz. high esteem and respect of heart, and the expression and testimony of it in words and actions.

So Edwards too sees glory in connection with praise, respect ("honor"), and admiration ("high esteem"). Indeed, we think the way Edwards connects glory to

1 The Hebrew verb $k b d$ and the corresponding noun kbôd along with the Greek verb doxazō and its corresponding noun doxa have all been translated as 'glory' in English. Between the Old Testament, New Testament, and the Septuagint these terms for glory occur approximately 897 times. BDAG (3rd edition; 2001) indicates that the noun can be used to mean "brightness, splendor, or radiance," and "being magnificent, greatness...fame, recognition, renown, honor, prestige." The entry for the verb states that it can refer to enhancing one's reputation and includes the idea of praise and honor as well as splendid greatness. Moisés Silva's revised NIDNTTE states that doxa is used in the New Testament, as it is in the Old Testament, to describe God's "transcendent being and majesty." The Hebrew lexica indicate that while both the verb and noun can denote being heavy, either literally or metaphorically, it can also refer to honoring another, enjoying or being honored, to boast, or cause another to be honored (HALOT, 455-56). DCH says much the same thing adding that the noun often refers to splendor or majesty (353). The Old Testament theological lexica, such as NIDOTTE confirm that this word group deals with "ascribing honor" to God often in public worship. While the English term 'admiration' does not always arise in discussions of the meaning of the relevant Hebrew and Greek terms for glory, the presence of the concept is, we think, clear. For, as we will discuss in detail below, part of what it is for something to be great and worthy of respect is for it to be valuable or worthy of esteem (i.e., admirable). 
praise, respect, and admiration in this passage is very close to how we should be thinking about what's at the core of our glory-concepts. But before we discuss this, we want to go just a bit deeper. For any illuminating account of our glory-concepts that connects them to praise, respect, and admiration should also say something about these further concepts in turn.

What is praise? Praise has to do with acts that commend something for its perceived characteristics. We praise artists for their genius, we praise theatrical performances for their subtle plots, we praise heroes for their courageous acts, we praise paintings for their use of color, etc. When we praise things we do so by performing acts of commendation. There are obviously many kinds of activity that can constitute an act of commendation. We can commend something by cheering, or by a loud declaration, or by writing a blog post, or by waiving our arms in a certain manner. These are all public acts of commendation (i.e., they are acts of commendation that others can notice). But we can also privately commend something by, say, simply inwardly affirming to ourselves how great it is. ${ }^{2}$

Yet, praise involves more than a mere act of commendation. It also has an internal evaluative aspect. J.J.C. Smart (1961: 303) observed this when he wrote that to praise something is to grade it, it is to give it a positive mark relative to some (assumed) evaluative standard. So praise is a kind of evaluative activity: it involves not simply commending something for it's perceived characteristics, but also believing those characteristics to be good in some way. We don't count as praising a painting by exclaiming out loud how beautiful it is if what we actually think is that the painting is rubbish. At most, we merely seem to be praising the painting by the lights of others. Put differently, we've performed a naked act of commendation. Edwards too seems to share this notion of praise in the quotation above when he characterizes praise as: "high esteem and respect of heart [= a positive inner attitude], and the expression and testimony of it in words and actions [= an act of commendation]."

One thing to note about praise is that it's not degreed. You can't praise something more or less in a strict sense; you either praise a performance or you don't. Yet it is possible to praise something more or less in a couple other, distinct senses. You can praise something more or less frequently, and in that sense, you might praise one performance more (often) than another. Further, chosen acts of praise can have more or less value. For example, praising a theatrical performance by asserting how compelling it was publicly in front of millions is in some sense "more valuable praise" than asserting the very same thing in private to your mirror. Both are acts of praise, but one of the two acts is (or can be) more valuable than the other. ${ }^{3}$

What is admiration? Admiration, like glory, is a nominalization and it has an attitude as its primary referent: we have admiration to the extent that we admire things. And admiring something has to do with valuing it. And this is not reducible to

\footnotetext{
${ }^{2}$ One question this raises is what makes an act an act of commendation. Our tentative opinion is that it has to do with whether or not that act would be interpreted as an act of praise by some contextually relevant group of people. For example, the reason a thumbs-up is an act of commendation is because it is normally used by us to praise something.

${ }^{3}$ This obviously raises interesting questions about the value of various sorts of praise-acts. But we'll leave that for the reader to reflect on.
} 
having a bare positive feeling towards something. For, like praise, admiration has an evaluative cognitive aspect: we only admire what we believe is good. It is, for example, hardly coherent to say that you admire a rubbish piece of music. Ross (1939: 278) noted this evaluative aspect of admiration when he wrote that "Admiration is not a mere emotion; it is an emotion accompanied by the thought that that which is admired is good." While both praise and admiration share a cognitive-evaluative aspect, they differ in kind. Praise is an activity, admiration is an attitude. Thus, like many other familiar attitudes, admiration is a dispositional state (i.e., a state one can be in even if one is not currently experiencing the state in a conscious way). For example, we believe in, and hope for, and fear many things. But these beliefs, and hopes, and fears don't cease to exist when we fall asleep or otherwise become temporarily unconscious. Similarly, our admiration for a painting can remain even when we are not currently experiencing our admiration for it (we might be distracted, asleep, etc.).

What is respect? The specific notion of respect (honor) that is most relevant in thinking about glory is the notion that Darwall (1977) has called "recognition respect". This notion of respect has two parts. The first involves having a behavioral disposition to interact with something in ways that befit it. For example, in normal circumstances we respect laws by obeying them, we respect paintings by displaying rather than destroying them, and we respect performances by not interrupting them. However, respect in this behavioral sense alone is not recognition respect. Recognition respect has a second aspect: it involves having this behavioral disposition in virtue of or because of one's belief that the object in question is deserving of respectful interaction (Darwall 1977: 40-41). Accordingly, we can think of respect in this sense as being an evaluative-behavioral disposition. Thus, for example, refraining from burning a painting solely because one wants to profit from it does not constitute having recognition respect for the painting any more than acting in friend-like ways towards someone solely because one sees financial profit in it constitutes friendship. One must behave respectfully because one believes respectful behavior is the behavior that is fitting towards the object.

There are two more things to note about this target notion of respect. First, one can have this kind of respect for something and yet neither admire nor otherwise directly value it. For example, lovers of modern art may not admire the work of the impressionists, but that doesn't mean they don't respect their work (we'll return to this). Second, it is a presupposition of this notion of respect that the characteristics of some objects ground fitting behaviors in relation to those objects. Of course, it is a substantive philosophical question what characteristics ground what range of fitting behaviors, and why this is so-we'll leave these explanatory questions for philosophers to answer elsewhere. For it is clear that objects can have characteristics that ground a range of fitting behaviors toward them. For example, it's clear that the Mona Lisa is deserving of being hung in a gallery rather than being hung upside-down in a portable bathroom even if, from a philosophical point of view, it's not immediately obvious what it is about that artwork that makes it deserving of being hung in a gallery rather than upside-down in a portable bathroom.

There is doubtless more to say about each of the above concepts of praise, respect, and admiration. But our existing grasp of these concepts together with the 
above remarks are enough for us to effectively begin thinking about what it is to glorify something.

So far we've only said that there is a conception of glorifying something that "connects" being glorified to praise, respect, and admiration. But what is that connection? Here's one way of connecting them to being glorified:

\section{Initial Characterization}

For something to be glorified by someone just is for someone to praise, and respect, and admire it for its (at least apparent) characteristics.

The 'just is' relation is an identity relation: it indicates that being glorified is the very same thing as being praised, and respected, and admired. Put differently, it indicates that there is nothing more to being glorified than being praised, and respected, and admired. Put differently still: it indicates that once we've said everything there is to say about being praised, and respected, and admired we've said everything there is to say about being glorified.

While this initial characterization of being glorified has a number of virtues it also faces serious problems. First, this account of being glorified makes the strong claim that being glorified requires both respect and admiration. Recall that Edwards also seemed to think this correct. But we believe this is too demanding. ${ }^{4} \mathrm{~A}$ fan of modern art might not "care for" (i.e., not admire) the impressionists. But that wouldn't prevent one from highly respecting their work. For example, just because someone doesn't admire impressionism doesn't mean they can't believe it to be good art, nor does it mean they will be inclined to burn or bash any piece of impressionistic art they come across. So respect in the absence of admiration is a real possibility. Accordingly, it seems like one can sincerely praise, say, Monet's works for being excellent works of art even if one fails to also admire his work. But in that case it seems perfectly fine to claim that one has glorified Monet's works by sincerely praising them.

Second, notice that respect and admiration come in degrees: you can have just a little respect for something, and you can have just a little admiration for something. But glorifying something surely includes more than just a little respect and just a little admiration. Yet the above account of being glorified fails to include any qualification to the effect that one's respect and admiration are more than minimal. ${ }^{5}$ Edwards identified the importance of this when he claimed that the sort of praise relevant to thinking about glory requires high esteem and respect.

Third, it seems possible to respect or admire something and, nevertheless, to insincerely praise it because one's motivations for praising it don't align with the reasons one has for praising. But as Edwards' characterization of glory cited above suggests: the sort of praise relevant to thinking about glory is praise that is an

\footnotetext{
${ }^{4}$ And we suspect Edwards took this line because he was seeking to characterize a theological ideal (i.e., praise towards God as it ought to be). On Edwards' view, one ought to respect and admire God, and one's praise should flow out of that.

${ }^{5}$ Perhaps there's nothing problematic with the idea of glorifying something just a little. If so, then the qualification relating to degrees won't matter. But we will still want to distinguish the robust cases of glorifying something from the less robust cases. This is what we've aimed to characterize above.
} 
"expression and testimony of" one's high esteem and respect of heart. This seems quite right to us. For example, suppose someone respects and admires God and also praises him by singing a song during a religious service. However, suppose further that their motivation for singing in the religious service is driven solely by peerpressure and their conscious attention is entirely focused on an upcoming sports match. In such a case one's praise will be in some sense insincere since it's not driven at all by one's respect or admiration for God. For in this example their praise is driven solely by the desire to avoid censure from one's peers.

One theological question this example raises is whether or not acts of insincere praise of God can be acts of glorifying God. ${ }^{6}$ But the main question this example raises is more general: can one glorify something with an insincere act of praise? We think not. It seems to us that glorifying anything (God or otherwise) requires that one's praise be sincere in the following sense: one's acts of praise are at least partially motivated by one's internal attitudes of respect or admiration. ${ }^{7}$ It's a fairly easy task to revise our account of being glorified in light of these three concerns:

\section{Being Glorified (primary)}

For something to be glorified by someone just is for someone to praise it as a result of either one's high degree of respect for it or their high degree of admiration for it (or as a result of both).

Insofar as we take significant sincere praise to be sincere praise that arises out of one's high degree of respect or admiration, we can simplify this idea:

For something to be glorified by someone just is for someone to significantly and sincerely praise it.

\footnotetext{
${ }^{6}$ A secondary question this raises is whether or not insincere praise is genuine praise or only merely apparent praise. We think insincere praise really is genuine praise. For recall that part of praising something involves positively evaluating it. It seems to us that when one commends something and one also views it as worth commending, one's act of commendation is an act of praise. Whether or not one disagrees with us on this point is inconsequential for the purposes of this paper. Since, either way, glorifying something will require that one's motivations align with one's act of commendation.

7 There's an additional question about the relation between praise, respect, and admiration raised here. Recall that praising something is a matter of expressing one's positive evaluation of something. Can one have a positive evaluation of something without respecting or admiring it? Put somewhat differently: is it possible to believe that something is good, but neither respect nor admire it? Granted, thinking that something is valuable and deserving of respectful interaction will tend to dispose one to value it and interact respectfully with it. But the connection here seems to be between distinct psychological states, and they seem to be contingently related to each other. We can easily believe that something is an instance of a good kind of thing-and so is itself good in some way-but nevertheless neither respect or admire that instance. For example, you might believe humans are valuable and deserving of respectful interaction, but still hate your enemy and actively seek his death. You might believe diamonds are valuable and should not be smashed, but hate diamonds that are heart-shaped and prefer they be destroyed. In more general terms: we can believe a type is valuable while not valuing all of its tokens. So we think it makes fine sense to speak of praising something (qua type) when you commend it for its positive characteristics, even if you neither admire nor respect it (qua token).
} 
This is, we believe, the primary sense of being glorified and that other senses of being glorified are to be understood in terms of it. We'll discuss other senses of 'being glorified' in section 4. In this regard it is worth noting that there are numerous cases where the activity of glorifying takes place in scripture and in none of the instances does the relevant text seem to indicate anything incompatible with the characterization of what it is to glorify an individual that we've just laid-out. We, of course, cannot make an exhaustive case for this claim here. For that would go beyond the scope and the length restrictions of this project. These scriptural examples include humans or divine beings who are glorifying (or exhorted to glorify) God (Josh 7:19; Judg 13:7; Pss 22:23; 50:15, 23; Prov 3:9; Isa 24;15; Jer 13:16; Matt 5:16; 9:8; Mark 2:12; Luke 17:18; Acts 12:23; Rom 4:20; Rev 4:9), humans glorifying other humans (Exod 20:12 Num 22:17; 1 Sam 2:29, etc.), or even God glorifying other people (1 Sam 2:30; $1 \mathrm{Chr}$ 17:18, cf. 17:8; 29:25, etc.). Glorifying someone can be done with verbal praise or cultic action but may also be done simply by how one lives their life (1 Cor 6:20). There are also many passages in which a person, inanimate objects, or abstract concepts are viewed as worthy of respect (honor), admiration (esteem), or praise (Gen 45:13; Exod 28:2, 40; 1 Sam 2:8; 2 Chr 1:11-12; 17:5; 18:1; Pss 8:5; 21:5; 84:11; Isa 43:7; 59:19; 60:13; Hag 2:3; Zech 2:8; Mal 1:6 Matt 4:8; John 11:4; Acts 7:55; Rom 1:23; Eph 1:17; 1 Pet 1:24; 2 Cor 3:10). Such passages seem to us to implicitly involve the idea of glorifying something (or of something being glorious), and our account of what it is to glorify something explains this.

\section{Being Glorious: A Fitting Attitude Account}

In the previous section we explained what is involved in glorifying something (in the primary sense): glorifying something is a matter of sincerely praising it, where the sincerity of one's praise has to do with it stemming from one's high degree of respect or admiration. But what of being glorious? And how is it related to being glorified?

One way of connecting the concept of being glorified with the concept of being glorious is to hold that being glorious just is a matter of being glorified:

\section{Initial Characterization}

For something to be glorious just is for it to be praised as a result of someone's high degree of respect or their high degree of admiration for it (or as a result of both).

This sounds quite close to what Cicero, Aquinas, and Edwards were saying in the citations above.

Some might worry that this account of being glorious makes it entirely pedestrian. After all, notions like "splendor" and "brilliance" and other luminosityinvoking terms seem central to how we think about being glorious, but the above account doesn't obviously include any luminosity language. We agree that an adequate account of glory will explain the deep connection between being glorious and luminosity. But we disagree that it must be explained in terms of what it is to be 
glorious. Rather, the best explanation will appeal to what it's like to experience something as glorious. We'll return to this issue in section 5 .

Still, there are other concerns with this characterization of what it is to be glorious. First, it implies that things fail to be glorious to the extent that they lack praise, respect, and admiration. That is, if there are no agents who in fact praise, respect, and admire something, then it fails to be glorious. But it's not conceptually incoherent to claim that something is glorious even if it's neither praised, nor respected, nor admired by anyone. For example, one could coherently think the universe was glorious in its earliest moments just after the Big Bang, and hence long before anyone was around to praise, respect, or admire it. 8

Second, this initial characterization of being glorious overlooks the evaluative character of glory. What is glorious is good. But the initial characterization of being glorious does not require that glorious things actually be good. Rather, it only requires that glorious things be regarded as good. For recall that praise, respect, and admiration all had an evaluative aspect: you cannot praise, respect, or admire what you don't regard as good. But something can be regarded as good without actually being good. So there is a problem here. For there is clearly something conceptually amiss in thinking that an object is glorious and not in fact good. More than that, what is glorious is not simply good. What is glorious is great. So one's account of being glorious should also imply that being glorious involves being great.

There's a straightforward way of fixing these problems with the initial characterization of being glorious. The fix involves taking a page out of the philosopher's handbook. For some time philosophers have been offering "fitting attitude analyses" of our thick evaluative concepts (i.e., evaluative concepts that have a descriptive component to them). This class of concepts includes the following: being excusable, being amusing, being credible, being desirable, being disgusting, being blameless, being blameworthy, etc. ${ }^{9}$ The basic insight of fitting attitude analyses is that there is a class of concepts which are to be understood in terms of the fittingness of an agent's attitude or response. The concept of being fitting is itself generally taken to be equivalent (or near equivalent for most practical purposes) to other broadly evaluative properties like being worthy, being appropriate, or being justified. Sometimes this whole class of notions is taken to be reducible to the idea of having sufficient reason. The idea being that what it is for someone's prospective attitude or response to be fitting (/appropriate/justified/worthy) just is for one to have sufficient reason for having that attitude or response. ${ }^{10}$

For example, consider the idea of something being desirable. Being desirable is a notion that is crucially tethered to the attitude of desire, but it also has an evaluative flare. For to say something is desirable is in part to evaluate desiring it (i.e., it is to say something about whether or not it is worthy of being desired). Put differently, to say that something is desirable just is to say that there is sufficient

\footnotetext{
${ }^{8}$ The fact that God might have been around is irrelevant; the point is that this thought makes sense, even if it's not in fact true.

${ }_{9}^{9}$ D'arms and Jacobson (2000), Zimmerman (2001), and Schroeder (2010).

${ }^{10}$ But this is not the place to take a stand on this issue. We'll just presuppose that being worthy is equivalent to these other notions and remain silent on the issue of reducibility.
} 
reason to desire it. Or take the notion of being blameworthy. For someone to be blameworthy just is for someone to be worthy of blame; or put differently, it is a matter of there being sufficient reason to blame them. You can see the fitting attitude strategy now. Take your target evaluative concept (e.g., being excusable, being amusing, being credible, being disgusting), and then separate it into two parts: a target attitude or response, and the fittingness of that response. We believe the analysis of glory is just one more place where the fitting attitude strategy offers assistance.

It's straightforward how to apply the fitting attitude theorist's formula to being glorious:

For something to be glorious just is for it to be worthy of being glorified.

Since we already have an account of what it is to glorify something we can be more informative than this. For recall from the previous section that glorifying something is a matter of significantly and sincerely praising it (i.e., praise that arises out of one's high degree of respect or admiration). So an alternative way of phrasing this is as follows:

\section{Being Glorious}

For something to be glorious just is for it to be worthy of significant and sincere praise.

This characterization of what it is to be glorious has several virtues.

First, it easily explains the evaluative nature of being glorious and the idea that something can be glorious while utterly lacking in actual praise, respect, and admiration from others. For, in general, being worthy of some kind of response does not depend on whether or not that response is actually received. A parent can be worthy of respect even if their child always fails to respect them.

Second, it also easily explains why it's so counterintuitive to think that it's possible for something to be glorious while also being unworthy of praise, respect, or of admiration. Consider the following conjunctions:

- The performance was glorious, but not worthy of praise.

- The performance was glorious, but not worthy of respect.

- The performance was glorious, but not worthy of admiration.

These are not sensible claims. It's quite intuitive to think that, say, a glorious performance is a performance that deserves praise, and respect, and admiration. Statements to the contrary will doubtless sound conceptually puzzling.

Third, it also explains why being glorious is goodness-entailing (i.e., why something cannot be glorious and fail to be good). Fitting attitude theories of goodness claim that being good just is a matter of being worthy of being valued. And since admiring something is a way of valuing it, it follows that something is worthy of admiration (in some respect) only if it is good (in that respect). Additionally, praise and respect were seen to have an evaluative aspect: to praise and respect something 
is, in part, to view it as good (in some regard). Accordingly, this suggests that only those things that are good (in that regard) will be worthy of praise and respect (in that regard).

Fourth, it can explain the idea that glory comes in degrees (i.e., some things can be more or less glorious). For something can be worthy of more or less praise, respect, and admiration.

Fifth, it can explain the fact that being glorious entails being great or excellent. How could, say, a performance be worthy of much praise, respect, and admiration but fail to be a great performance?

All of these factors support the general idea that the fitting attitude analysis of being glorious offered above is an accurate analysis of what it is to be glorious.

\section{Derivative Senses of Glory}

We've explained what we take to be the main senses of what it is to be glorious (section 3) and to be glorified (section 2). But there are yet further glory-concepts that merit discussion due to their inclusion in theological reflection. Several of these senses figure into the work of Jonathan Edwards. After introducing these concepts we'll turn to see how they are present in the work of Edwards, and how they can all be thoroughly understood in terms the accounts we've offered above of being glorious and being glorified.

Sometimes people talk about a film glorifying violence or a selfless act glorifying God. But films can't praise anything nor can they respect or admire anything. The same is true of actions: a selfless act cannot praise anything. Only agents can praise, respect, and admire things; and films and actions are not agents in any sense of the term.

Some might try to accommodate the idea that a film can glorify violence by treating it as simply a way of saying that filmmakers glorify violence with a film. Perhaps this really is the thought people sometimes intend to express when they say that a film glorifies violence. But it cannot always be the best way to understand such claims. For there is still some sense in which it's correct to say films like the Matrix or Die Hard glorify violence even if their filmmakers were horrified by violence (and so neither respect nor admire violence) and thus that these filmmakers somehow did not intend their films to be ways of praising violence. When this is the case, in what sense might we say that the film glorifies violence?

We think talk of films (music, art, etc.) glorifying violence, or love, or heroism, etc., are frequently best understood in terms of the way in which films (music, art, etc.) tend to incite their viewers to glorify violence. That is, when people watch these films they are "carried along" in such a way that they find themselves-at least temporarily-admiring or respecting the film and its violent aspects, and for this reason become disposed to praise it as well. So there is a secondary notion of "being glorified" that can be understood in terms of the primary notion above:

Being Glorified (secondary) 
For something, $x$, to be glorified (in this secondary sense) by something, $y$, just is for $y$ to tend to incite people to glorify (=significantly and sincerely praise) $x$.

We think that it is in this sense that selfless acts, miracles, sermons, and other nonagents can be said to glorify God: for certain selfless acts, miracles, sermons, and so forth really tend to incite people to glorify (=significantly and sincerely praise) God. The thing to notice is that this is a derivative concept of being glorified (i.e., a concept whose meaning is given in part by the primary sense of being glorified developed in section 2). ${ }^{11}$

Derivative senses of being glorified don't end there. Consider someone claiming that a painter's masterpiece glorifies the painter, or that God's creation (the universe) glorifies God. Again, we have the same problem here that works of art and the universe aren't the sort of things that can sincerely praise anything since they are not agents. Yet these claims are meaningful. So what's the meaning?

A natural way of understanding these sorts of claims involves the way in which an effect (the masterpiece, the universe) can inform others about the glory-making properties of its cause (the painter, God). That is, if something is glorious (=worthy of being significantly and sincerely praised) there are some facts about that thing that make it worthy of being glorified. The master painter is glorious in virtue of his artistic genius, and the master painter's work of art puts that artistic genius on display. Put differently: the work of art puts others in a position to recognize his artistic genius, a property which makes him worthy of being glorified. Similarly with God: God is glorious in virtue of (among other things) his creative genius and great power, and his creation (the universe) puts those attributes of his on display (i.e., the universe puts others in a position to recognize his creative genius and great power).

Accordingly, we can characterize this further sense of glorifying as follows:

Being Glorified (tertiary)

For something, $x$, to be glorified (in this tertiary sense) by something, $y$, just is for $y$ to tend to put people in a position to recognize $x$ 's attributes that make $x$ glorious (=worthy of being significantly and sincerely praised).

The secondary and tertiary senses are obviously related. Think again of the relationship between the master painter and his masterpiece. His masterpiece glorifies him in the secondary sense (=it tends to incite others to significantly and sincerely praise him) because it glorifies him in the tertiary sense (=it tends to puts others in a position to recognize his attributes that make him worthy of being

\footnotetext{
${ }^{11} \mathrm{~A}$ referee suggested that some films (e.g., Pulp Fiction) may glorify violence even though most viewers don't glorify violence upon watching the film. Rather, most viewers are truly horrified and repulsed by violence. This potential counterexample is managed in one of two ways. Either it's not literally true that such films glorify genuine violence (as opposed to fictional violence), or it is literally true and the tendency to incite people to glorify genuine violence is masked in the way that dispositions can generally be masked by additional factors that prevent the manifestation of the disposition.
} 
significantly and sincerely praised). ${ }^{12}$ But that doesn't imply that these two derivative senses collapse into each other. For example, an artistic genius might be widely yet falsely believed to be both anti-Semitic and physically abusive to women (i.e., people are just mistaken about these facts). He's neither anti-Semitic nor abusive. Never the less, this widely spread false belief can bring it about that his masterpieces do not tend to incite others to praise him even though his masterpieces $d o$ put others in a position to recognize his artistic genius - the property that makes him worthy of significant and sincere praise. Interestingly, in Romans 1:18-25 Paul the Apostle suggests this kind of separation between the secondary and tertiary notions of being glorified. There he seems to indicate that God has ensured that people are aware of him and his attributes that make him glorious. Yet people are corrupt to such an extent that this knowledge does not incite them to significantly and sincerely praise God.

These secondary and tertiary senses of being glorified can be found throughout the Old and New Testament. We include them together since, in many contexts, these senses overlap. For example, in Psalm 79:9 the psalmist asks for help for the sake of God's glory. We take this to mean that if and when God does decide to help it will both put people in a position to recognize that God is worthy of being glorified and also incite those same people to then glorify God (in the primary sense). God is often said to act not just for the blessing of his people, but also so that he might be seen as glorious throughout the nations (Ezek 39:13; Isa 63:14). We have already mentioned Psalm 19:1 in which the heavens are said to "declare the glory of God." We add that creation both puts others in a position to see that God is worthy of being glorified and tends to incite at least some to actually praise him. Again, elsewhere people are exhorted to live their lives in such a way so that it incites others to glorify God (Matt 5:16; cf. Matt 6:2 negatively of hypocrites). Elsewhere, God says he will set his glory among the nations which will then cause them to see the judgment and power of God (cf. Exod 14:4; Isa 40:5; Hab 2:14). The implication is, again, that God is acting in such a way that people are being put into a position to recognize that God is worthy of being glorified and also incites those same people to then glorify God (in the primary sense). In many instances even the physical manifestation of the glory of God covers multiple senses. The revelation of God's presence, especially when it is accompanied with images of light and fire and smoke and beauty and strength, conveys that the very nature of his being is worthy of being glorified. In these contexts it is often shone forth precisely in order to put people in a position to recognize that he is glorious and then to incite them to respond by glorifying him (Exod 16:7, 10; 24:16, 17; 29:43; 33:18, 22; 40:34, 35; Lev 9:6, 23; Num 14:10; 1 Sam 4:21-22; Psa 26:8; 63:2; 85:9 Isa 3:8; 4:5; Ezek 1:28; 3:12, 23; 8:4; 9:3; 10:4; Luke 2:9; Acts 9:2; 22:6, $11 \operatorname{Rev} 21: 23)$.

\footnotetext{
${ }^{12}$ It is our suspicion that there are further related senses of "being glorified". For example, the tertiary sense articulated above requires that people be in a position to recognize an object's features that make it glorious. But that requires that something actually have such glory-making properties. But we can imagine cases of misattribution where this fails to be the case. Suppose we were to misattribute a masterpiece to a very mediocre painter. Our misattribution would lead us to glorify (=significantly and sincerely praise) him, and there would be a further, related sense in which the masterpiece glorifies him because of our misattribution. But that's obviously not a central sense of the term 'glorifies' and it's one that's best understood in terms of other senses we've already put forth.
} 
There is one further sense of 'glory' we'd like to discuss. It's the sense in which people "glory in" things. People sometimes glory in their achievements. People also sometimes glory in the achievements of other people (think of parents glorying in their child's accomplishments). People sometimes glory in the achievements and accomplishments of groups they're a part of or at least support (think of republicans glorying in the election of Bush, or sports fans glorying in the success of their favorite teams). This kind of glorying is a common phenomenon.

Now there is a sense of 'glorying-in' that has to do with boasting-in something. Central to this sense is the way in which one seeks to increase one's own standing among other people by drawing attention to their own accomplishments or else identifying themselves in some way with the accomplishments of others (the accomplishments of their children, their politicians, their teams, etc.). Notice that this "boasting sense" of glory-in just seems to be related to the third derivative notion of being glorified with an added emphasis on one's motivations for glorifying something. That is:

\section{Glorying-in (boasting sense)}

For $x$ to glory in $y$ (in this boasting sense) just is for $x$ to attempt to put others in a position to recognize that $y$ is glorious with the aim of increasing $x$ 's respect and admiration from others by identifying with y in some way.

In addition to this, there is a further sense of glorying-in that's relevant. It's a sense that's more closely associated with reveling-in and has to do with enjoying something that one takes to be glorious. That is,

Glorying-in (reveling sense)

For someone to glory in something just is for one to enjoy what one regards as glorious.

For example, Jonathan Edwards (Miscellany 448) has this notion in mind when he writes that:

God is glorified within himself...by appearing or being manifested to himself in his own perfect idea; [and] by enjoying and delighting in himself, by flowing forth in infinite love and delight towards himself, or, in his Holy Spirit.

There is more to this quote than we're able to discuss here. But it is clear that Edwards' underlying idea is that God glories in himself in that God recognizes that he is glorious, and he enjoys it.

Further instances of glorying-in (boasting and reveling senses) can be found if we also briefly consider an examination of kauch-roots. In the Old Greek (OG) of Deut 10:21, God says that he is Israel's "boast" who has done great and glorious things ( $t a$ endoxa tauta) for them. In Deut 26:19 God tells Israel that he will set them above all other nations since he has made them a boast and glorious (kauchèma kai doxaston; cf. Deut 33:29). In 1 Chr 16:35, David thanks God and asks him to save and gather Israel so that they might praise God and boast in his praiseworthy acts (kauchasthai 
en tais ainesesin sou). Sometimes it is difficult to decide whether a text is employing the boasting sense of glorying-in or the reveling sense (or both). For example, in Pss 11:5, all who trust and love God are exhorted to boast and exalt in him (kauchēsontai en soi; cf. also Pss 32:11). In Jeremiah, the boasting sense seems to, at times, be more clearly indicated. For example, in Jer 9:22-23, the prophet commands his hearers not to boast in wisdom or strength or wealth but in the knowledge that Yahweh exercises judgment and mercy and righteousness upon the earth. In Jer 13:11, Israel, because God binds himself to them, will be a famous people, a glory and a boast (eis kauchèma kai eis doxan). In texts such as Pss 149:5 and Isa 24:14 though, we see more clear examples of the reveling sense of glorying-in. Both of these texts refer to exuberant joy, and God's people are reveling in the activity of praising God. Similarly, in the so called apocalypse of Isaiah (25:1), in the midst of sincere and joyful praise of God we read: "O Lord God, I will glorify you because you have done wonderful things..." Most likely, it is the primary sense of glorifying something which makes the most sense in this context. And yet it is also hard to deny that the person engaged in such praise is deeply enjoying what he regards as glorious. The very act of glorifying another may, in certain contexts, implicitly include glorying-in (reveling sense) the other.

Similar statements can be found in the New Testament, especially in Paul's epistles. In Phil 3:3 we read that those of the true circumcision worship by means of the Spirit and glory in (boast in; kauchōmetha) Jesus Christ. In Rom 5:2-3, Paul explains that through Jesus believers have obtained grace in which they not only stand but in which they also boast, where this boasting is based upon the hope of God's glory (kauchōmetha ep' elpidi tēs doxēs tou theou). We again find it difficult in this case to decide whether Paul is employing kauchōmetha in the sense of boasting or reveling sense of glorying-in, and we think it plausible he may be employing both. The term "hope of glory" here appears to refer to the future consummation in which believers will finally be perfected and restored-a future state that is glorious. Using the term 'glory' as a euphemism for eternal life or eschatological reward is common in Paul (cf. Rom 2:7 and 2:10).

To summarize the philosophical contributions above. We have the following distinct concepts the term 'glory' has been used to express. The insight to appreciate is that all of them trace back to the activity of glorifying something in the primary sense discussed in section 2 :

\begin{tabular}{|l|l|}
\hline $\begin{array}{l}\text { being glorified } \\
\text { (primary) }\end{array}$ & being significantly and sincerely praised \\
\hline being glorious & being worthy of being glorified (=sig. \& sinc. praised) \\
\hline $\begin{array}{l}\text { being glorified } \\
\text { (secondary) }\end{array}$ & inciting people to glorify (=sig. \& sinc. praised) something \\
\hline $\begin{array}{l}\text { being glorified } \\
\text { (tertiary) }\end{array}$ & $\begin{array}{l}\text { putting people in a position to recognize something's } \\
\text { attributes that make it worthy of being glorified (=sig. \& } \\
\text { sinc. praised) }\end{array}$ \\
\hline
\end{tabular}




\begin{tabular}{|l|l|}
\hline $\begin{array}{l}\text { glorying-in } \\
\text { (boasting sense) }\end{array}$ & $\begin{array}{l}\text { attempting to put people in a position to recognize } \\
\text { something's attributes that make it worthy of being } \\
\text { glorified (=sig. \& sinc. praised) in order to increase one's } \\
\text { respect and admiration from others by identifying with it } \\
\text { in some way }\end{array}$ \\
\hline $\begin{array}{l}\text { glorying-in } \\
\text { (reveling sense) }\end{array}$ & $\begin{array}{l}\text { enjoying what one regards as glorious (=worthy of being } \\
\text { sig. \& sinc. praised) }\end{array}$ \\
\hline
\end{tabular}

This set of glory-concepts is deeply unified. For they are all to be understood in terms of being significantly and sincerely praised, which is in turn to be understood in terms of praise arising from one's high degree of respect or admiration. This is what lies at the core of all our glory-concepts, and it is what explains why talk of glory is so frequently accompanied by talk of praise, respect (honor), and admiration (esteem, valuing).

Having a grip on these distinct notions of glory can be useful when reading theology. For example, Jonathan Edwards (Miscellany 448) packs many of these notions together under the one term 'glory', and at first blush, it can seem confusing just why this is so:

So God glorifies himself towards the creatures also [in] two ways: (1) by appearing to them, being manifested to their understandings; (2) in communicating himself to their hearts, and in their rejoicing and delighting in, and enjoying the manifestations which he makes of himself. They both of them may be called his glory in the more extensive sense of the word, viz. his shining forth, or the going forth of his excellency, beauty and essential glory ad extra. By one way it goes forth towards their understandings; by the other it goes forth towards their wills or hearts. God is glorified not only by his glory's being seen, but by its being rejoiced in...

To our modern English ears, the phrase "God glorifies himself to his creatures" is odd and initially unclear. But given the rest of Edwards' explanatory remarks and given the conceptual resources developed above we can quickly and clearly (though perhaps less elegantly) re-express Edwards' core thoughts in this passage:

First, God glorifies himself in the tertiary sense described above (i.e., he puts people in a position to recognize that he is glorious). He does this by putting people in a position to recognize his attributes that make him glorious. ${ }^{13}$

Second, in glorifying himself in that tertiary way, God also glorifies himself in a further (indeed fourth!) derivative way. For in putting people in a position to recognize that he is glorious he also puts them in a position to glory-in that

\footnotetext{
13 We're here assuming that part of what is involved in God "manifesting himself to [our] understandings" is for God to put people in a position to know certain facts about himself. Which facts? Those that are relevant to recognizing that God is glorious, which we (and presumably Edwards) would take to involve facts about God's power, love, wisdom, redemptive acts, etc.
} 
fact. That is, he puts his creatures in a position to recognize that he is glorious and to enjoy it.

So here we see three of our glory-concepts being deployed by Edwards: being glorified (tertiary), being glorious, and glorying-in (reveling sense). There is also a quaternary sense of the term 'being glorified' that Edwards introduces: putting others in a position to glory in something. Given the previous account of glorying-in discussed above we can see that this further concept of being glorified that Edwards draws our attention to is nothing more than this:

Being Glorified (quaternary)

For $x$ to glorify $y$ (in this quaternary sense) just is for $x$ to tend to put people in a position to glory in $y$ (in the revel sense) (i.e., to recognize that y is glorious and enjoy it).

So the meaning of Edwards' additional glory-concept is rendered explicit by the gloryconcepts that we've already offered.

\section{Luminosity: What it's Like to Experience Glory}

There is doubtless some kind of connection between our glory-concepts and luminosity. Often when people seek to characterize glory they at some point employ language that evokes imagery of light. For instance, C. S. Lewis (1941) wrote that glory suggested two ideas to him, "either glory means to me fame, or it means luminosity." 14 Bavinck (2004: 252, 253) writes:

The "glory of the Lord" is the splendor and brilliance that is inseparably associated with all of God's attributes and his self-revelation in nature and grace... ${ }^{15}$

Biblical texts speak of the earth shining with the glory of the Lord (Ez 43:2), and the Lord reigning in glory in a way that outshines the sun and moon (Is 60:1-2). During Jesus' transfiguration the glory of the Lord shone around the disciples (Luke 2:9). Revelation 18:1 describes an angel whose glory lights the earth. Since our characterization of being glorious fails to include luminosity-invoking concepts in any way, one might think our characterization is in some way problematic. We disagree.

Consider the following two questions: What is orange juice? And, what is it like to drink orange juice? These are two distinct questions. The first question is about the nature of a certain beverage. The second question is about the nature of one's experience of that beverage. We would answer the second "what it's like" question by saying that the experience of drinking orange juice is "refreshing", "sweet", and

\footnotetext{
${ }^{14}$ We think the primary concept of being glorified nicely explains why Lewis found it intuitive to regard glory in connection to fame. For being famous (as opposed to infamous) is often a matter of being glorified (sincerely praised) by others.

${ }^{15}$ Bavinck (2004: 254) treats this language as metaphorical not specifying the true nature of glory.
} 
"zesty". But these concepts would not figure into our answer to the first question about what orange juice is. Orange juice just is juice squeezed from actual orangesor something close to that. So our answer to the first question will look very different from our answer to the second, and that's because they are simply very different questions.

Our thesis is that luminosity language is so often used in connection with glory because it aptly (albeit metaphorically) characterizes our experiences of things that are glorious. Why is luminosity language apt in this way? We suspect it's because the experience of encountering something one takes to be glorious is broadly similar to the experience of encountering something that is visually bright. To see the connection, start by reflecting on initial encounters you had with something you were inclined to identify as glorious. That is, reflect on the first time you saw your favorite movie, or the first time you heard some stunning bit of music, or some occasion where you saw a uniquely compelling sunset. When we experience something as glorious our experience is as of being consciously and involuntarily pulled to respect and admire it and then to give voice to this felt welling of respect and admiration by praising it. There's something it's like to have this kind of experience, and part of what it's like involves having one's attention profoundly arrested by the glorious object. That which is glorious tends to seize our attention and force other possible objects of attention to fade into the background. In this way, experiencing something as glorious is a lot like having a very bright light appear in one's visual field: the bright light seizes one's perceptual attention and pulls one's attention away from other objects in one's visual field. It is our suspicion that it's this common kind of experience (the experience of having one's attention arrested by an object) that has lead people to, over time, take terms that are tethered to visual imagery of light and use them to express thoughts about glory.

More than that, there are a range of things people have tended to regard as glorious that are actually visually bright: the sun, the moon, lightning, fire, stars, jewels, polished rare metals, fireworks, modern concert performances with attendant light displays, modern visual media (projections, TV and computer displays, etc.). The fact that humans historically and presently associate brightness with things that are glorious (or at least taken to be glorious) is also, we suspect, at least partially responsible for the connection between our thoughts about the connection between glory and luminosity. ${ }^{16}$

So there is a kind of two-pronged explanation for the conceptual connection between glory and luminosity: our encounters with things we regard as glorious is similar to our encounters with visually bright objects, and certain paradigmatically glorious objects really are visually bright. But neither fact is itself a reason to think that in order to be glorious something must be visually bright. Indeed, people readily take things like mathematical proofs, modern technology, and scientific

\footnotetext{
${ }^{16}$ Similarly, bright light is often a part of biblical descriptions of God revealing his glory to people. But we needn't take these descriptions to be invoking metaphor given that bright light is not literally a part of what it is to be glorious. The authors of these passages may in fact be asserting that God was reveling his glory in part by creating great visual displays involving light.
} 
understanding of the physical world to be glorious even though visual brightness is not an actual feature of these things.

To conclude, we've argued that our glory-concepts are many. But they also display an underlying unity. For all of them can be understood in terms of the primary sense of being glorified (i.e., being significantly and sincerely praised). Indeed, we think this is the criterion for being a glory-concept: it must be at least partially understood in terms of this primary sense of being glorified. Our hope is that this short project will have provided the kind of clarity needed to motivate and inspire new perspectives on exegetical, theological, and philosophical questions about glory in years to come. 


\section{References}

Aquinas, Thomas. 1920. The Summa Theologica of St. Thomas Aquinas. 2nd and revised edition. Translated by the Fathers of the English Dominican Province. $\begin{array}{lll}\text { Accessed November } & 2018 .\end{array}$ http://www.newadvent.org/summa/3132.htm.

Bauer, Walter. (with Arndt/Gingrich/Danker). 2001. A Greek-English Lexicon of the New Testament and Other Early Christian Literature. (BDAG). 3rd edition. Revised and edited by Frederick William Danker. University of Chicago Press.

Bavinck, Herman. 2004. Reformed Dogmatics, vol. 2 of 4. Edited by John Bolt. Translated by John Vriend. Baker Academic.

Cicero. 1949. “De Inventione.” In On Invention. The Best Kind of Orator. Topics., Loeb Classical Library 386. Translated by H. M. Hubbell. Cambridge, MA: Harvard University Press. Accessed November 15, 2018. https://www.loebclassics.com/view/marcus_tullius__icerode_inventione/1949/pb_LCL386.333.xml?rskey=IPzXD8\&result=2.D'arms, Justin and Daniel Jacobson. 2000. "Sentiment and Value.” Ethics 110 (4): 722748.

Darwall, Stephen. 1977. “Two Kinds of Respect.” Ethics 88 (1): 36-49.

Dictionary of Classical Hebrew, vol. IV (of 8). 1988. Edited by David. J. A. Clines. Sheffield Academic Press (DCH).

Edwards, Jonathan. 1989. Ethical Writings. Vol. 8 of The Works of Jonathan Edwards. Edited by Paul Ramsey. Yale University Press.

1994. The "Miscellanies": Entry Nos. a-z, aa-zz, 1-500. Vol. 13 of The Works of Jonathan Edwards. Edited by Thomas A. Schafer. Yale University Press.

Hobbes, Thomas. (1651)2017. Leviathan. Accessed November 15, 2018. http://www.earlymoderntexts.com/assets/pdfs/hobbes1651part1 2.pdf.

Ganass, George E. 1991. Ignatius of Loyola: Spiritual Exercises and Selected Works. Edited by George E. Ganass, S.J. Paulist Press.

Lewis, Clive Staples. 1941. “The Weight of Glory.” Theology 43 (257): 263-274.

Richardson, M. E. J., ed. 2001 The Hebrew and Aramaic Lexicon of the Old Testament (HALOT), vol. 2 of 5. E. J. Brill.

Ross, William David. 1939. Foundations of Ethics. Oxford: Clarendon Press.

Schroeder, Mark. 2010. "Value and the Right Kind of Reason." In Oxford Studies in Metaethics, edited by Russ Shafer-Landau, Vol. 5, 25-55. Oxford University Press. 
Silva, Moisés. 2014. New International Dictionary of New Testament Theology and Exegesis. (NIDNTTE), vol. 1 of 5. Zondervan.

Smart, John Jamieson Carswell. 1961. "Free Will, Praise and Blame." Mind 70 (279): 291-306.

VanGemeren, Willem. 1998. New International Dictionary of Old Testament Theology and Exegesis. (NIDOTTE), vol 2 of 5. Zondervan.

Zimmerman, Michael. 2001. The Nature of Intrinsic Value. Rowman \& Littlefield Publishers. 